\title{
Impulse Response Functions and Causality Test of Financial Stress and Stock Market Risk Premiums
}

\author{
Vichet Sum \\ Assistant Professor, School of Business and Technology \\ Department of Business, Management and Accounting, University of Maryland - Eastern Shore \\ Kiah Hall, Suite 2117-A Princess Anne, MD 21853, USA \\ Tel: 410-651-6531 E-mail: vsum@umes.edu
}

Received: October 16, 2012

Accepted: November 12, 2012

Online Published: December 16, 2012

doi:10.5430/ijfr.v4n1p1

URL: http://dx.doi.org/10.5430/ijfr.v4n1p1

\begin{abstract}
Using the vector autoregressive (VAR) framework, this study empirically documents the impulse response functions of financial stress and market risk premiums and performs a causality test of these two variables. The analysis of the monthly changes of the Federal Reserve Bank of St. Louis Financial Stress Index and excess returns on the CRSP value-weighted index from 1994:2 to 2012:5 shows that market risk premiums become negative in the first, second and third, fourth and twelfth months following the financial stress shock. The degree of financial stress drops in the first, second, fourth, fifth, seventh, tenth months following risk premium shock. There is no observed feedback response from financial stress to market risk premium shock. The Granger causality test results show that financial stress Granger-causes market risk premiums to drop significantly, and there is no reverse causation recorded in this case. In addition, the time-series OLS regression analysis shows a statistically significant negative coefficient $(\mathrm{b}=$ $-8.50 ; \mathrm{t}=-9.20)$ when explanatory variable is the monthly changes in financial stress.
\end{abstract}

Keywords: Financial stress, Stock market risk premiums

\section{Introduction}

The health of the financial sector can have significant direct and indirect effects on the real economy because this sector is responsible for saving mobilization and credit allocation across time and space. In addition, the financial sector provides payment and fund transfer services which are vital to both businesses and consumers; households and businesses can also use various financial products to maximize their utility and manage potential risks. Therefore, a healthy financial sector should lower the cost and risk of producing and trading of goods and services among market participants. Likewise, when the financial sector is healthy, credit should become more available and the cost of finance should be more affordable, on average. Credit availability and low cost of finance are favorable conditions for consumption and investment which are key to economic growth and prosperity.

Nonetheless, when the financial sector is stressful, the real economy can be severely affected. Businesses, consumers, and financial institutions are hesitant to invest, spend, and extend credit when the financial sector is stressful (Hakkio \& Keeton, 2009); tightened credit availability can lead to a significant jump in the cost of credit. Higher cost of finance is negatively linked to firms' capital expenditure and investments (Gilchrist et al., 2010; Fernandez-Villaverde et al., 2012). The economy can contract when firms postpone potential investment projects (Bernanke, 1983). Investment delay means potential layoff and freeze of hiring resulting in a higher unemployment rate in the economy.

Market participants in the financial markets most likely reduce their holding of risky financial assets such stocks and increase their holding of safer assets such the U.S. treasuries when the financial sector becomes stressful - a flight-to-quality phenomenon. The flight to quality should put downward pressure on the stock markets. Up to this point, little is known about the how stock market responds to financial stress shock. Therefore, it is the problem of this study to empirically document how stock market risk premiums respond to financial stress and to test the causal link between financial stress and stock market risk premiums. This study is necessary because it adds vital information to the current literature and contributes to the further understanding of the dynamic relationship between financial stress and stock market performance; it is also important for asset valuation and risk management. 


\section{Method and Data}

Monthly excess returns on the CRSP value-weighted index from 1994:1 to 2012:5 are obtained from Kenneth's data library located at http://mba.tuck.dartmouth.edu /pages/faculty /ken.french/data library.html. The monthly financial stress data from 1994:1 to 2012:5 are obtained from the Federal Reserve Bank of St. Louis. The detailed methodology of how the index is constructed is available on the Federal Reserve Bank of St. Louis' website located at http://research.stlouisfed.org/publications/net/NETJan2010Appendix.pdf. A vector autoregression (VAR) analysis, a system of equation (1) and (2), is carried out to determine the impulse response functions between financial stress and stock market risk premiums. The Granger causality Wald tests are also performed to determine if financial stress and economic policy uncertainty causes each other. The time-series OLS regression analysis (equation 3 ) is carried to determine the effect of financial stress on stock market risk premiums.

$$
\begin{gathered}
R_{m t}-R_{f t}=\alpha+\sum_{i=1}^{p} \lambda_{i}\left(R_{m t-i}-R_{f t-i}\right)+\sum_{i=1}^{p} \varphi_{i} \Delta F S_{t-i}+\varepsilon_{t} \\
\Delta F S_{t}=\alpha+\sum_{i=1}^{p} \lambda_{i}\left(R_{m t-i}-R_{f t-i}\right)+\sum_{i=1}^{p} \varphi_{i} \Delta F S_{t-i}+\varepsilon_{t} \\
R_{m t}-R_{f t}=\alpha+\beta \Delta F S_{t}+\varepsilon_{t}
\end{gathered}
$$

Where:

$R_{m t}=$ Return on CRSP value-weighted index (\%) in time $t$

$R_{m t-i}=$ Return on the CRSP value-weighted index (\%) in time $t-i$

$R_{f t}=$ One-Month Treasury bill rate (\%) in time $t$

$R_{f t-i}=$ One-Month Treasury bill rate (\%) in time $t-i$

$\Delta F S_{t}=$ change in the index of financial stress by taking the first difference; that is the value of financial stress index in month $t$ less month $t-1$

$\Delta F S_{t-i}=$ change in the index of financial stress in month $t-i$

\section{Results}

Before performing the vector autoregression analysis, Schwarz's Bayesian information criterion (SBIC), the Akaike's information criterion (AIC), and the Hannan and Quinn information criterion (HQIC) tests are performed to determine the appropriate length of lags to be included in the model. Four lags are recommended by the tests. As shown in Table 1, the VAR results show that the market risk premiums become negative in the first, second and third, fourth and twelfth months following the financial stress shock. The degree of financial stress drops in the first, second, fourth, fifth, seventh, tenth months following risk premium shock. There is no observed feedback response from financial stress to market risk premium shock. The Granger causality test results, reported in Table 2, show that financial stress Granger-causes market risk premiums to drop significantly, and there is no reverse causation recorded in this case. In addition, the time-series OLS regression analysis shows a statistically significant negative coefficient $(b=-8.50 ; t=-9.20)$ when explanatory variable is the monthly changes in financial stress.

\section{Conclusion}

The problem of this study is to empirically document how stock market risk premiums respond to financial stress and to test the causal link between financial stress and stock market risk premiums. The analysis of the monthly changes of the Federal Reserve Bank of St. Louis Financial Stress Index and excess returns on the CRSP value-weighted index from 1994:2 to 2012:5 shows that market risk premiums become negative in the first, second and third, fourth and twelfth months following the financial stress shock. The degree of financial stress drops in the first, second, fourth, fifth, seventh, tenth months following risk premium shock. There is no observed feedback response from financial stress to market risk premium shock. The Granger causality test results show that financial stress Granger-causes market risk premiums to drop significantly, and there is no reverse causation recorded in this case. In addition, the time-series OLS regression analysis shows a statistically significant negative coefficient when explanatory variable is the monthly changes in financial stress.

A limitation of this study is a small number of observations; only 18 years of data are available. Another limitation is 
that this study does not examine the relationship between stock market risk premiums and financial stress in different sub periods. A direction for future research is to duplicate this study with data from other countries since this study only analyses data from the United States.

\section{References}

Bernanke, B. (1983). Irreversibility, uncertainty and cyclical investment. Quarterly Journal of Economics, 98, 85106. http://dx.doi.org/10.2307/1885568

Fernandez-Villaverde, J, Guerron-Quintana, P., Kuester, K., \& Rubio-Ramirez, J. (2012). Fiscal volatility shocks and economic activity. University of Pennsylvania mimeo.

Gilchrist, S., Jae W. Sim, S. J., \& Zakrajsek, E. (2010). Uncertainty, financial friction and investment dynamics. Working paper, Boston University and Federal Research Board.

Hakkio, C. S., \& Keeton, W. R. (2009). Financial stress: What is it, how can it be measured, and why does it matter? Economic Review, 5-50.

Table 1. Impulse Response Functions (IRF) of Market Risk Premiums (MRP) to Financial Stress (FS) Shock

\begin{tabular}{ccc}
\hline Step & IRF of MRP to FS Shock & IRF of FS to MRP Shock \\
\hline 1 & -2.39238 & -0.00592 \\
2 & -0.32271 & -0.00128 \\
3 & -3.01994 & 0.00750 \\
4 & -2.85811 & -0.00212 \\
5 & 0.13330 & -0.00117 \\
6 & 0.05546 & 0.00125 \\
7 & 0.18690 & -0.00104 \\
8 & 0.48658 & 0.00004 \\
9 & 0.06908 & 0.00027 \\
10 & 0.04673 & -0.00029 \\
11 & 0.03210 & 0.00016 \\
12 & -0.07530 & 0.00004
\end{tabular}

Table 2. Granger Causality Walt Tests

\begin{tabular}{ccccc}
\hline Equation & Excluded & chi2 & df & Prob $>$ chi2 \\
\hline$R_{m}-R_{f}$ & $\Delta \mathrm{FS}$ & 12.99 & 4 & 0.011 \\
$R_{m}-R_{f}$ & All & 12.99 & 4 & 0.011 \\
$\Delta \mathrm{FS}$ & $R_{m}-R_{f}$ & 4.39 & 4 & 0.356 \\
$\Delta \mathrm{FS}$ & All & 4.39 & 4 & 0.356 \\
\hline
\end{tabular}

Table 3. Time-Series OLS regression results

\begin{tabular}{lcccc}
\hline & Coefficient & Std. Err. & $\boldsymbol{t}$ & Sig. \\
\hline Constant & 0.51 & 0.27 & 1.91 & 0.058 \\
$\Delta F S$ & -8.50 & 0.92 & -9.20 & 0.000 \\
R-Square & 0.279 & & & \\
Adj. R-Square & 0.276 & & & \\
F $(1,218)$ & 84.71 & & & 0.000 \\
\hline
\end{tabular}

Number of Observation $=220$; Durbin-Watson d-statistic $(2,220)=1.931185$ 
Table 4. Durbin's alternative test for autocorrelation

\begin{tabular}{cccc}
\hline $\operatorname{lags}(\mathrm{p})$ & chi2 & df & Prob $>$ chi2 \\
\hline 1 & 0.185 & 1 & 0.6675 \\
\hline
\end{tabular}

Null Hypothesis: no serial correlation

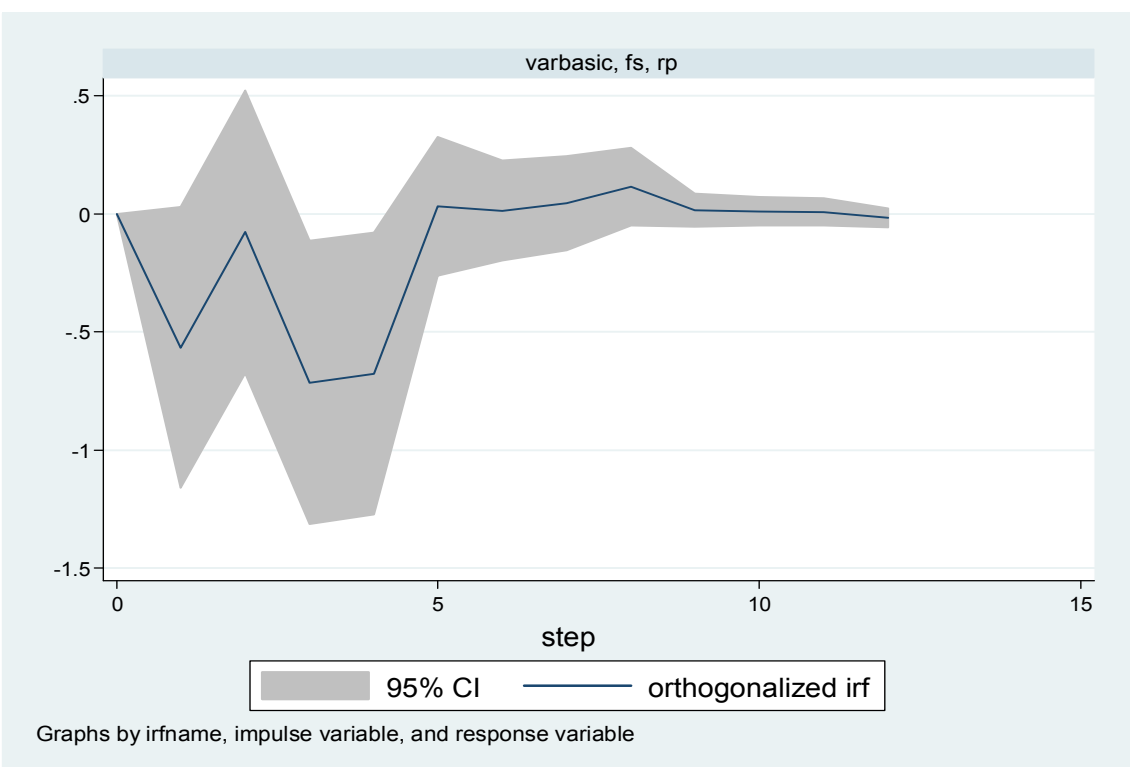

Figure 1. The Orthogonal Impulse Response Function (OIRF) of stock market risk premiums to financial stress

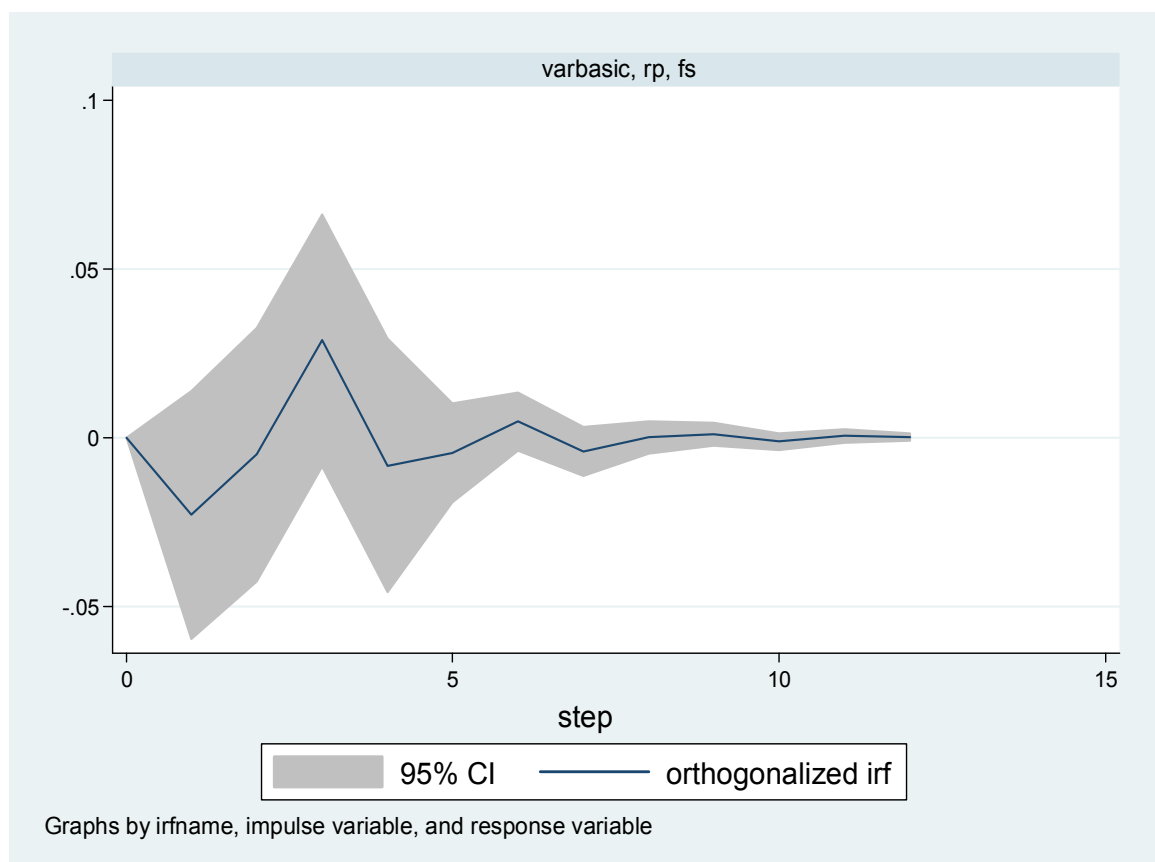

Figure 2. The Orthogonal Impulse Response Function (OIRF) of financial stress to stock market risk premiums 